\title{
PENERAPAN GROUP GESTALT THERAPY BAGI WARGA BINAAN LAPAS NARKOTIKA X YANG MENGALAMI KECEMASAN MENJELANG BEBAS
}

\author{
Imelda Konghoiro ${ }^{1}$ Sandi Kartasasmita ${ }^{2}$, Untung Subroto ${ }^{3}$ \\ ${ }^{1}$ Jurusan Psikologi, Universitas Tarumanagara Jakarta \\ Email:konghoiroimelda@gmail.com \\ ${ }^{2}$ Jurusan Psikologi, Universitas Tarumanagara Jakarta \\ Email:sandik@fpsi.untar.ac.id \\ ${ }^{3}$ Jurusan Psikologi, Universitas Tarumanagara Jakarta \\ Email:undhar@yahoo.com
}

\begin{abstract}
ABSTRAK
Selama menjalani masa pidana di lapas, warga binaan (tahanan) akan kehilangan hak kebebasan sehingga kebebasan dari masa pidana merupakan hal yang sangat ditunggu oleh warga binaan. Namun tidak sedikit warga binaan merasakan kecemasan karena bingung menghadapi masa depan saat kembali berada di tengah masyarakat terutama ketika harus menghadapi pandangan negatif dari masyarakat. Oleh sebab itu dibutuhkan terapi untuk mengurangi kecemasan yang dirasakan oleh warga binaan. Terdapat beberapa teknik terapi untuk mengatasi kecemasan, salah satunya adalah terapi kelompok gestalt. Tujuan terapi kelompok ini untuk mengurangi kecemasan warga binaan dengan mengaplikasikan terapi kelompok gestalt. Terapi ini mampu mengatasi perasaan yang belum selesai (unfinished problems) yaitu kecemasan warga binaan menjelang kebebasan dengan lingkungannya masingmasing dengan menerapkan teknik kursi kosong (empty chair). Partisipan dalam penelitian sebanyak lima orang. Partisipan akan diminta untuk bertukar peran dan berdialog dengan sumber kecemasannya. Partisipan juga akan diminta untuk melakukan relaksasi terlebih dahulu agar partisipan dapat merasa lebih tenang. Relaksasi yang digunakan yaitu breathing exercise dan progressive muscle relaxation (PMR).Intervensi dilakukan sebanyak enam sesi. Hasil akan diukur dengan membandingkan skor pretest-posttest dari Beck Anxiety Inventory. Setelah dilakukan intervensi, partisipan menunjukkan penurunan skor kecemasan pada skor posttest. Selama intervensi berlangsung, partisipan mampu mengikuti intervensi dengan cukup positif. Sehingga didapatkan hasil penurunan skor pada saat posttest diberikan. Hal ini menunjukkan adanya penurunan tingkat kecemasan pada warga binaan menjelang bebas.
\end{abstract}

Kata kunci: kecemasan, warga binaan, terapi kelompok gestalt, menjelang bebas.

\section{PENDAHULUAN \\ Latar Belakang}

Seseorang yang melanggar norma hukum sehingga harus dijatuhi hukuman pidana dan menjalani kesehariannya sebagai warga binaan di sebuah Lembaga Permasyarakatan (Lapas). Warga binaan merupakan sebutan bagi narapidana dan tahanan yang melanggar norma hukum sehingga harus menjalani masa pidana di lapas Selama berada di dalam lapas, warga binaan mengalami banyak perubahan dalam kehidupannya, berupa kehilangan hak kebebasan untuk waktu tertentu dan keterbatasan untuk bertemu dengan keluarganya. Sehingga kebebasan dari masa pidana adalah hal yang sangat ditunggu oleh kebanyakan warga binaan namun terkadang juga menimbulkan perasaan takut dan khawatir.

Menjelang kebebasannya warga binaan biasanya merasakan permasalahan seperti permasalahan psikologis (Fahrulina, 2011). Permasalahan psikologis berupa depresi, stres, dan kecemasan karena bingung menghadapi masa depan. Namun menurut Utari et al. (2012), kecemasan merupakan gangguan psikologis yang umumnya muncul pada warga binaan saat menjelang masa pembebasannya. 
Menurut Taylor (1953), kecemasan adalah suatu perasaan subjektif mengenai ketegangan mental yang menggelisahkan sebagai reaksi umum dari ketidakmampuan mengatasi suatu masalah atau tidak adanya rasa aman. Seseorang akan mengalami kecemasan jika tidak mampu mengatasi stressor psikososial yang dihadapinya. Kecemasan yang berlebih akan menghambat fungsi seseorang dalam kehidupannya. Dampak kecemasan dapat mencakup fisik dan psikis. Dampak fisik yang dialami berupa sakit kepala, kurang nafsu makan, sulit tidur dan merasa lemas. Sedangkan dampak psikis yang dialami berupa perasaan tidak aman, bingung, tertekan, dan gelisah (Taylor, 1953).

Kondisi inilah yang terjadi pada RR, FA, AM, HI dan ZM menjelang bebas kurang lebih enam bulan lagi. RR, FA, AM, HI dan ZM adalah warga binaan yang berada di lapas yang akan mendapatkan kebebasan sekitar enam bulan lagi. Menjelang kebebasannya, mereka merasakan perasaan cemas atau khawatir. Hal ini didukung dengan data yang dikumpulkan oleh pemeriksa melalui observasi dan wawancara secara personal serta kuesioner mengenai kecemasan yang menunjukkan bahwa ke lima warga binaan tersebut sedang mengalami kecemasan.

Kecemasan ini terjadi karena warga binaan memiliki ketakutan dan kekhawatiran dalam menghadapi masa depan saat kembali dalam lingkungan masyarakat baik itu lingkungan keluarga, pekerjaan maupun lingkungan sekitar. RR, FA, AM, HI dan ZM mengalami kecemasan mengenai masa depannya bebas dari lapas. Mereka memiliki ketakutan karena belum siap ketika menghadapi dunia luar setelah menjalani masa hukuman di lapas. Mereka cenderung takut lingkungannya tidak dapat menerimanya kembali dan bagaimana pandangan masyarakat terhadap warga binaan. Warga binaan juga bingung tentang apa yang harus dilakukan dan apakah rencana yang telah mereka susun akan berhasil setelah warga binaan bebas dari lapas.

Karena pertimbangan pentingnya untuk mengurangi kecemasan maka dibuatlah intervensi. Intervensi ditujukan untuk mengurangi kecemasan dengan menyadarkan mereka tentang keadaan mereka sekarang dan meningkatkan kualitas hubungan interpersonal dengan lingkungan yang akan mereka hadapi nantinya. Intervensi ini penting untuk membantu mereka sadar akan kondisi mereka saat ini sehingga mampu menghadapi lingkungan baik keluarga, pekerja atau masyarakat yang menjadi sumber kecemasan mereka. Hal ini akan membantu mereka untuk menyelesaikan perasaan mereka yang belum selesai yaitu kecemasan sehingga mampu menghadapi lingkungan masyarakat ketika mereka bebas.

\section{Rumusan Masalah}

Apakah terapi kelompok gestalt dapat menurunkan kecemasan pada warga binaan menjelang kebebasan di lapas narkotika X?

\section{Tujuan Penelitian}

Terapi kelompok ditujukan untuk mengurangi kecemasan yang dialami dengan memberikan kesadaran akan keadaan mereka saat ini dan juga menyelesaikan perasaan yang belum selesai yaitu kecemasan sehingga mampu menghadapi lingkungan ketika kembali ke masyarakat.

\section{METODE PENELITIAN \\ Partisipan Penelitian}

Karakteristik partisipan yaitu: warga binaan di lapas narkotika X, akan bebas kurang lebih 6 (enam) bulan lagi, warga binaan mengalami kecemasan menjelang kebebasan. 


\section{Desain Penelitian}

Desain penelitian yang digunakan dalam penelitian ini adalah mixed method dengan menggabungkan metode penelitian secara kuantitatif dan kualitatif dalam satu penelitian. Penelitian ini menggunakan pre-test dan post-test sebagai analisa untuk menentukan kriteria partisipan dan mengetahui perbandingan hasil sebelum dan sesudah pemberian intervensi.

\section{Lokasi Penelitian}

Lokasi Penelitian dilakukan di lapas narkotika X.

\section{Instrumen Penelitian}

Peralatan yang digunakan adalah lembar informed consent, kursi kosong, dan kuesioner Beck Anxiety Inventory.

\section{Pengukuran}

Alat ukur yang digunakan adalah Beck Anxiety Inventory untuk mengetahui tingkat kecemasan warga binaan menjelang bebas. Alat ukur terdiri dari 19 pernyataan untuk mengukur tingkat kecemasan warga binaan. Kuesioner ini memiliki reliabilitas 0,95 dan validitas 0,83. Hal ini menyatakan bahwa Beck Anxiety Inventory valid dan reliable untuk mengukur tingkat kecemasan warga binaan menjelang bebas.

\section{Prosedur Penelitian}

Dalam menentukan kesamaan kelompok menggunakan data yang diperoleh oleh pihak lapas yaitu data mengenai warga binaan yang akan bebas kurang lebih enam bulan lagi. Kemudian, terapis melakukan pretest dengan membagikan kuesioner tentang kecemasan agar dapat melihat tingkat kecemasan yang dialami oleh warga binaan yang mengaku mengalami kecemasan menjelang kebebasannya. Selanjutnya terapi kelompok gestalt dilakukan. Setelah itu, dilakukan protest dengan memberikan kuesioner kecemasan untuk mengetahui perubahan pada tingkat kecemasan warga binaan.

\section{Pelaksanaan Penelitian}

Metode yang digunakan adalah terapi kelompok Gestalt yang dimulai dengan initial stage atau tahap perkenalan terlebih dahulu dengan tujuan untuk mencairkan suasana. Kemudian merumuskan aturan-aturan dalam kelompok yang harus dipatuhi oleh semua anggota agar terapi dapat berjalan dengan lancar dan terarah. Terapis juga memberitahu mengenai tujuan dari terapi dan apa yang ingin dicapai melalui terapi ini. Setelah itu, masuk ke transition stage dimana pada tahap ini terapi memberikan psikoedukasi mengenai kecemasan dan memberi pemahaman mengenai masalah yang sedang dihadapi oleh warga binaan saat ini. Kemudian terapi gestalt dilanjutkan dengan melakukan konfrontasi kepada anggota kelompok untuk memberikan kesadaran bahwa mereka adalah mantan narapidana sehingga ketika warga binaan kembali ke tengah masyarakat, maka masyarakat pasti akan memberikan pandangan yang cenderung negatif pada mereka sebagai mantan narapidana. Hal ini penting untuk membuat kelompok sadar akan kondisinya saat ini. Selain itu, ada beberapa anggota yang cenderung denial terhadap kondisinya saat ini dengan mengatakan mereka hanyalah narapidana karena kasus narkoba dan bukan kriminal jadi tidak sama dengan narapidana dengan kasus kriminal seperti mencuri atau membunuh sehingga masyarakat seharusnya tidak memiliki pandangan negatif terhadap mereka. 
Setelah mereka sadar dan menerima keadaan saat ini, kemudian terapis masuk ke dalam working stage dimana terapis akan mengarahkan anggota untuk membawa kecemasan dan kekhawatiran mereka tentang masa depan ke masa sekarang. Jadi kelompok akan seolah-olah sedang menghadapi kekhawatirannya tersebut saat ini. Teknik yang digunakan adalah teknik kursi kosong (empty chair). Teknik ini bertujuan untuk membantu mengatasi konflik interpersonal dan intrapersonal. Pada teknik ini terapis akan menggunakan dua kursi. Terapis meminta salah satu anggota kelompok untuk duduk di satu kursi dan berperan sebagai diri sendiri dengan tujuan agar anggota dapat menghadapi kekhawatiran secara langsung. Kemudian anggota kelompok tersebut berpindah ke kursi yang lain dan berperan sebagai hal yang dikhawatirkannya dengan tujuan agar anggota dapat mengetahui secara verbal apa yang ingin mereka dengar dari orang yang menjadi sumber kecemasannya (Corey, 2012). Teknik digunakan karena sangat cocok dengan permasalahan dalam kelompok yang dengan menghadirkan kecemasan mereka terhadap lingkungan baik keluarga, pekerjaan atau lingkungan masyarakat dan dapat diselesaikan dengan penerimaan dan integrasi antara kedua peran tersebut.

Namun sebelum anggota kelompok bertukar peran, anggota akan diminta untuk melakukan relaksasi yaitu breathing exercise dan progressive muscle relaxation (PMR). Breathing exercise dilakukan agar udara dapat masuk ke dalam tubuh sehingga oksigen dapat menyebar ke seluruh tubuh sehingga anggota kelompok dapat merasa lebih tenang. Breathing exercise dilakukan secara sederhana yaitu dengan cara menutup mata sambil mengatur pernapasan. Anggota kelompok akan diminta untuk mengatur pernapasan dengan menarik napas yang dalam kemudian dihembuskan secara perlahan. PMR dilakukan untuk mengurangi ketegangan dan kecemasan pada anggota kelompok. Relaksasi ini dilakukan dengan cara menegangkan sekelompok otot tertentu kemudian melepaskan ketegangan itu. Kedua relaksasi ini diberikan agar anggota kelompok dapat merasa rileks sebelum anggota kelompok menghadapi kecemasannya. Selain itu, teknik ini sangat cocok untuk mengatasi perasaan yang belum selesai (unfinished emotions) yaitu kecemasan warga binaan menjelang kebebasan dengan lingkungannya masing-masing. Terapis akan mengarahkan klien untuk berbicara dengan sumber kecemasannya. Pelaksanaan teknik ini dapat berupa monolog dimana orang yang diajak berbicara di kursi kosong tidak menjawab atau dapat berupa dialog dimana orang tersebut menjawab seperti yang mungkin dijawab orang tersebut.

\section{HASIL DAN PEMBAHASAN}

Sesi pertama dilakukan pada Selasa, 02 Mei 2017 berlokasi di ruangan konseling yang berada di lapas narkotika X. Pada sesi ini, pemeriksa memperkenalkan masing-masing anggota kelompok dan mencairkan suasana. Selanjutnya, pemeriksa menjelaskan mengenai tujuan dari pembentukan kelompok ini serta merumuskan aturan dalam kelompok dan meminta pendapat anggota kelompok menceritakan tentang permasalahan mereka masing-masing. Anggota kelompok juga diminta untuk memberikan pendapat mereka tentang aturan dalam kelompok yang harus mereka patuhi selama terapi kelompok ini berjalan. Selain itu, pemeriksa juga meminta kesediaan dan komitmen dari anggota kelompok untuk mengikuti terapi ini dari pertemuan awal sampai akhir. Sesi ini berjalan dengan baik dan anggota mampu memberikan pendapat dengan aktif dan baik.

Sesi kedua dilakukan pada hari Kamis, 04 Mei 2017. Pada sesi ini pemeriksa memberikan psikoedukasi tentang kecemasan serta memberikan pemahaman tentang masalah yang dihadapi sekarang. Anggota terlihat memahami penjelasan yang diberikan oleh pemeriksa dan beberapa kali terlihat mengangguk. Pemeriksa juga melakukan konfrontasi berupa memberikan kesadaran 
pada anggota kelompok tentang pandangan masyarakat yang pasti akan mereka hadapi ketika mereka bebas dan kembali ke masyarakat sehingga anggota kelompok harus siap dan mampu menghadapi hal tersebut. Anggota kelompok memahami hal tersebut. ZM juga menanyakan mengenai apa yang bisa mereka lakukan untuk mengurangi rasa kecemasan yang mereka hadapi saat ini. Pemeriksa menjawab bahwa itulah tujuan dari kelompok ini dibuat dan meminta setiap anggota untuk terus mengikuti terapi dengan teratur. Pada pertemuan ini pemeriksa menjelaskan terapi yang akan dilakukan yaitu terapi kelompok gestalt dengan teknik empty chair dan anggota kelompok memahami hal tersebut.

Kemudian, pemeriksa juga mengajarkan teknik relaksasi kepada anggota kelompok yaitu terapi pernapasan dan terapi relaksasi otot yang akan mereka lakukan pada awal sesi pertemuan sebelum masing-masing anggota menghadapi kecemasannya. Hal ini dilakukan untuk membuat anggota kelompok mampu rileks sebelum menghadapi kecemasannya. Pemeriksa juga memberitahukan jika anggota kelompok secara bergantian akan memimpin relaksasi di setiap sesi terapi. Pemeriksa juga memberikan kuesioner kecemasan Beck (1988) dengan reliabilitas 0,95 dan validitas 0,83 .untuk diisi oleh semua anggota kelompok.

Sesi ketiga dilakukan pada hari Selasa tanggal 09 Mei 2017. Pada sesi ini terlebih dahulu dimulai dengan relaksasi pernapasan yang dilakukan semua anggota kelompok yang dipimpin oleh ZM sesuai dengan intruksi yang telah diajarkan oleh pemeriksa pada sesi sebelumnya. Terapi gestalt dimulai oleh ZM yang akan menghadapi kecemasannya. Kursi kosong kemudian di letakkan tepat di depan ZM dan pemeriksa meminta ZM untuk mulai menghadirkan kecemasannya. ZM mengatakan akan menghadirkan tetangganya yang dinilai berperan sangat penting di sekitar lingkungan rumahnya. ZM mulai menutup matanya, menarik napas yang dalam dan mengutarakan isi hatinya kepada sosok yang dihadirkan oleh ZM pada kursi kosong tersebut. Setelah itu, ZM bertukar peran menjadi sosok tetangga yang dihadirkan sebelumnya dan mengutarakan apa yang ZM harapkan mampu dikatakan oleh tetangganya tersebut. Kemudian, pemeriksa meminta anggota kelompok yang lain untuk memberikan pendapat dan saran terhadap ZM. Selanjutnya ZM kembali menghadirkan orang tua pacarnya dan mulai mengutarakan apa yang akan dikatakan ZM kepada mereka ketika ZM bebas dan bertemu dengan mereka. ZM juga bertukar peran menjadi orang tua pacarnya dan mengucapkan kata-kata yang diharapkan dikatakan oleh orang tua pacar ZM kepadanya. Terakhir, ZM menghadirkan neneknya dan meminta maaf sebesar-sebesarnya serta berjanji akan menjadi orang yang lebih baik lagi dari sebelumnya kemudian ZM juga bertukar peran menjadi neneknya. Selanjutnya pemeriksa meminta anggota yang lain memberikan pendapatnya masing-masing. Setelah menghadapi kecemasannya dan bertukar peran, ZM mengaku merasa lebih baik dan menjadi lebih legah serta berterima kasih kepada pemeriksa dan anggota kelompok yang lain.

Selanjutnya, giliran RR yang akan menghadapi kecemasannya. RR mengambil posisi yang nyaman dan meletakkan kursi tepat di depannya. RR akan menghadirkan sosok ayahnya. RR mulai menarik napas yang dalam serta menutup matanya dan mulai mengatakan kata-kata yang akan dikatakan RR kepada ayahnya dengan meyakinkan ayahnya jika RR akan membuktikan jika yang ayahnya katakan pada RR selama ini salah serta meminta maaf atas kesalahan RR yang sudah RR lakukan selama ini seperti masuk penjara. RR kemudian bertukar peran menjadi ayahnya dan mengatakan apa yang diharapkan RR dikatakan oleh ayahnya. Selanjutnya, RR menghadirkan istrinya yang beberapa bulan terakhir sudah tidak pernah berkomunikasi dengan RR. RR ingin meminta maaf atas kesalahan RR selama ini dan meminta kejelasan mengenai hubungan pernikahan mereka serta menanyakan alasan mengapa istrinya tidak pernah 
menjenguk RR selama RR berada di penjara. Kemudian RR berganti peran menjadi istrinya kemudian anggota kelompok yang lain memberikan pendapat dan tanggapan.

Sesi keempat berlangsung pada hari Jumat tanggal 12 Mei 2017. Sesi dimulai dengan melakukan relaksasi otot yang dilakukan anggota kelompok dan dipimpin oleh HI. Setelah melakukan relaksasi, HI mulai mengatur posisi duduk yang nyaman dan meletakkan kursi kosong di depannya. Saat ini, HI menghadirkan sosok ayah yang telah sering dikecewakan oleh HI selama ini. HI menarik nafas yang dalam, menutup matanya dan mulai meminta maaf kepada ayahnya karena sering kali membohongi ayahnya mengenai memakai narkoba. HI kemudian bertukar mejadi ayahnya dan mengatakan apa yang HI harapkan ayahnya katakan karena ayah HI sudah sering kali mengatakan hal ini kepadanya. Kemudian HI menghadirkan teman baiknya (S) yang sejak dulu merintis usaha komputer bersamanya tetapi karena HI sering memakai narkoba sehingga HI tidak memperdulikan usaha mereka tersebut. HI meminta maaf kepada $S$ dan bertanya kepada $S$ mengenai prospek usaha komputer yang sebelumnya pernah mereka jalankan bersama. HI juga bertukar peran dan mengharapkan mengatakan prospek usaha komputer masih dapat HI lakukan. Selanjutnya anggota yang lain memberikan pendapat dan tanggapan mereka masing-masing mengenai apa yang sudah dilakukan oleh HI. Selanjutnya, giliran AM yang akan menghadapi kecemasannya. AM akan menghadirkan orang tua terlebih dahulu. AM mulai menutup matanya dan mengatakan bahwa AM meminta maaf atas semua yang pernah AM lakukan serta akan mencoba mencari pekerjaan yang halal dan berusaha untuk tidak kembali lagi menjual narkoba. AM kemudian bertukar peran menjadi orang tuanya. AM selanjutnya menghadirkan omnya dan mengatakan apa yang terjadi sebenarnya yaitu selama ini AM masuk kembali ke dalam penjara, meminta maaf dan meminta omnya untuk memahami keadaannya dan tidak menyalahkan orang tua AM yang berbohong kepadanya. AM juga bertukar peran menjadi omnya. Setelah itu, pemeriksa meminta anggota kelompok yang lain untuk memberikan pendapat dan tanggapan terhadap AM.

Sesi kelima berlangsung pada hari Selasa tanggal 16 Mei 2017. Sesi ini dimulai dengan relaksasi pernapasan yang dipimpin oleh FK dan diikuti oleh semua anggota kelompok. Pada sesi ini FK yang akan menghadapi kecemasannya. FK cukup sulit ketika diminta untuk menghadirkan kecemasannya dan cenderung menolak untuk melakukannya. Namun setelah pemeriksa memberikan dukungan dan penjelasan, FK akan mencoba mendatangkan kecemasannya tersebut. Sebelumnya, FK menceritakan jika FK merasa bersalah dan takut menghadapi keluarga ibunya karena FK merasa keluarga besar ibunya telah menganggap bahwa FK yang harus bertanggung jawab atas kematian ibunya. FK mulai menarik nafas yang dalam, menutup mata dan diam sejenak. FK mulai meminta maaf kepada ibunya sambil menangis dan mengatakan mengapa semua orang seperti menyalahkannya atas meninggalnya ibu FK. FK menangis cukup lama dan mengatakan banyak hal. Setelah selesai, FK perlahan-lahan membuka matanya dan pemeriksa memberikan tisu kepada FK serta meminta anggota yang lain untuk memegang bahu FK serta menepuk bahu FK sebagai salah satu tanda untuk mendukung FK. FK merasa sedikit lebih lega setelah menghadirkan ibunya. Setelah cukup tenang, FK kemudian melanjutkan ntuk menghadirkan kecemasannya yang lain yaitu ayahnya. FK meminta maaf kepada ayahnya dan akan mencoba memiliki hubungan yang lebih dekat dengan ayahnya dan akan mendengarkan semua yang ayah FK katakan kepadanya. FK kemudian bertukar peran menjadi ayahnya. Selanjutnya anggota kelompok memberikan tanggapan dan pendapatnya masing-masing terhadap FK. 
Sesi keenam berlangsung pada hari Kamis tanggal 18 Mei 2017 selama kurang lebih satu setengah jam. Pada sesi ini, pemeriksa mengulang semua yang telah dilakukan sebelumnya dari sesi pertama sampai kelima. Pemeriksa juga memberitahukan bahwa sesi ini adalah sesi terakhir namun bukan berarti perjuangan mereka berakhir tetapi akan terus berlanjut sampai mereka benar-benar bebas dan kembali berada di lingkungan masyarakat. Pemeriksa juga melakukan evaluasi secara keseluruhan dari kegiatan yang sudah dilakukan selama ini. Anggota merasa sangat terbantu dan merasa lebih baik serta legah setelah mengikuti terapi yan dilakukan. ZM juga mengatakan bahwa ZM merasa sedikit sedih karena menyadari jika pertemuan akan segera berakhir dan akan merindukan berada di dalam kelompok. HI juga menambahkan bahwa HI merasa sangat berterima kasih dengan pemeriksa dan anggota kelompok yang telah memberikan saran untuknya. Sebelum menutup sesi, pemeriksa memberikan kembali kuesioner kecemasan untuk melihat perubahan yang terjadi kepada anggota kelompok.

Tabel 1. Hasil Intervensi Seluruh Subyek

\begin{tabular}{lll}
\hline Inisial & Pretest & Posttest \\
\hline ZM & 29 & 2 \\
RR & 28 & 9 \\
HI & 22 & 3 \\
AM & 19 & 7 \\
FK & 24 & 7 \\
\hline
\end{tabular}

\section{KESIMPULAN DAN SARAN}

Secara keseluruhan, terapi kelompok yang telah berlangsung berjalan dengan baik dan memberikan perubahan pada anggota kelompok. Anggota kelompok merasa lebih tenang dan legah setelah mengikuti terapi kelompok serta mampu mengurangi kecemasan yang dirasakan oleh anggota kelompok saat ini menjelang kebebasannya. Masing-masing anggota menjadi lebih siap menghadapi kebebasannya dan menghadapi masyarakat nantinya. Selain itu, anggota kelompok juga mendapatkan dukungan dari sesama anggota untuk menjadi lebih baik di masa depan dan berkomitmen untuk menjauhi narkoba. Tujuan utama dari terapi kelompok gestalt telah tercapai dengan baik. Tujuan terapi yaitu mengurangi kecemasan yang dialami oleh anggota kelompok menjelang kebebasan telah berhasil dilakukan. Hal ini terutama berlaku bagi ZM yang terlihat sangat mendapatkan manfaat dari terapi yang telah dilakukan. HI, RR dan AM juga mendapatkan manfaat dari terapi namun FK perlu mendapatkan terapi tindak lanjut berupa terapi individu untuk menghilangkan rasa bersalah yang masih dirasakan oleh FK karena kematian ibunya. Namun secara keseluruhan, terapi telah mampu mengurangi rasa cemas yang dialami oleh anggota kelompok menjelang kebebasannya nanti.

\section{Diskusi}

Penerapan terapi kelompok gestalt secara efektif membantu menurunkan tingkat kecemasan pada lima warga binaan di Lapas Narkotika X. Hal ini terlihat pada kelima partisipan selama menjalani proses intervensi. Selain itu juga terlihat dari penurunan skor posttest. Dengan demikian dapat disimpulkan bahwa terapi gestalt adalah terapi yang tepat mengingat 
keterbatasan dalam menjalankan terapi lain di dalam lapas. Hal tersebut sesuai dengan hasil penelitian Serok (2006) yang mengatakan bahwa terapi gestalt mampu menurun kecemasan pada murid di sekolah. Garcia (2007) juga mengungkapkan bahwa terapi gestalt mampu menurunkan kecemasan pada mahasiswa yang sedang menyelesaikan disertasi. Terapi gestalt merupakan terapi utama dalam penelitian ini di mana breathing exercise dan progressive muscle relaxation (PMR) hanya dilakukan untuk membuat partisipan relaks sebelum memulai terapi gestalt. Materi yang disampaikan dalam kelompok telah sesuai dengan rancangan yang telah dibuat sebelumnya, dengan durasi pertemuan sekitar 1,5 jam hingga dua jam yang berlangsung di ruangan konseling di lapas narkotika X. Selama sesi intervensi, intervensi dilakukan selama satu hingga dua jam disesuaikan dengan diskusi kelompok yang dilakukan.Secara umum, respon masing-masing anggota setelah mengikuti intervensi cukup positif. Selama terapi berlangsung, setiap anggota mampu memberikan pendapatnya dengan baik, namun FK dan ZM adalah anggota yang paling aktif dalam memberikan pendapat dan tanggapan sedangkan AM, RR dan HI lebih banyak mengikuti pendapat anggota yang lain. Semua anggota mampu mengikuti instruksi dan terapi dengan baik namun FK harus diberikan dukungan lebih yang lebih intensif untuk menghadapi kecemasan namun proses terapi berlangsung dengan baik. Menurut anggota kelompok, intervensi telah mengurangi rasa khawatir dan takut yang sebelumnya mereka rasakan. Secara keseluruhan, intervensi telah berjalan dengan baik dan telah mampu membantu anggota kelompok untuk mengurangi kecemasan yang dirasakan menjelang kebebasannya. Proses intervensi pun berjalan sesuai dengan rencana. Namun, terdapat beberapa keterbatasan dalam penelitian ini yaitu ketidakhadiran dari beberapa partisipan yang jatuh sakit atau sedang mengikuti acara di lapas menyebabkan intervensi yang dilaksanakan kurang efektif pada beberapa partisipan. Selain itu, keterbatasan dalam jumlah kehadiran partisipan dan sulitnya ruangan untuk melakukan intervensi membuat proses intervensi harus beberapa kali dibatalkan dan dipindahkan ke pertemuan berikutnya. Keterbatasan lainnya yaitu tidak diketahuinya bahwa penurunan skor tingkat kecemasan yang terjadi karena intervensi atau adanya faktor di luar intervensi. Hal ini karena tidak adanya kelompok kontrol yang dapat dijadikan sebagai pembanding.

\section{Saran}

Secara umum, kelompok disarankan mampu merealisasikan terapi yang telah dilakukan sebelumnya sehingga anggota kelompok mampu menghadapi lingkungan sekitarnya ketika mereka bebas nanti. Untuk penelitian berikutnya, dapat dipertimbangkan untuk menggunakan teknik terapi gestalt selain empty chair. Karena dalam penelitian ini, hanya menggunakan teknik empty chair. Selain itu, disarankan untuk menambahkan jumlah partisipan pada penelitian ini sehingga hasil yang didapatkan dapat lebih akurat dan juga mampu meningkatkan hubungan interpersonal dan interaksi sosial antar partisipan serta memberikan dukungan sosial pada masing-masing partisipan.

\section{REFERENSI}

Corey, G. (2012). Theory and Practice of Group counseling (8th ed.). CA: Brooks/ColeThomson Learning

Fahruliana, R. (2011). Pengaruh Pemberian Terapi Humor Terhadap Penurunan Tingkat Kecemasan Pada Narapidana Menjelang Masa Pembebasan Di Lembaga Permasyarakatan Wanita Kelas IIA. Malang: UIN.

Garcia, C. L. (2007). Dialectic dialogue for academic anxieties in the dissertation process. California: University of Arizona. 
Nolen, S.H. (2014). Abnormal psychology (6th ed.). Boston: McGraw-Hill

Serok, S. (2006). The application of gestalt methods for the reduction of test anxiety in students. Assessment \& Evaluation in Higher Education, 16(2), 157-164.

Sharf, R. S. (2012). Theories of psychotherapy and counseling: Concepts and cases. Belmont, CA: Cengage Learning.

Taylor, J. A. (1953). A personality scale of manifest anxiety. The Journal of Abnormal and Social Psychology, 48(2), 285-290

Utari, et al. (2012). Gambaran tingkat kecemasan pada warga binaan wanita menjelang bebas di lembaga pemasyarakatan wanita kelas IIA bandung. Student E-Journals, 1(1), 1-15. 